\title{
8
}

\section{Other Views of Northern Australian Aspirations: Pre-Notions, Ideologies and Remoteness}

\author{
Judith Lovell and Don Zoellner
}

\section{Introduction}

This chapter explores ideology and remoteness through the configuration of markets and non-markets that operate in a sparsely settled region in Northern Australia. As non-Indigenous researchers analysing data from Aboriginal settlements, we acknowledge the primary and overarching configuration in these settlements is Aboriginal sovereignty and the standpoints of local residents and custodians (Ardill, 2013; Morrison, 2015; Nakata, 2007). A previous study of 15 remote Aboriginal settlements in the region (see Figure 8.1) revealed that certain mixedmarket activities (aboriginal art centres, Indigenous ranger programs and Aboriginal community researchers) have remained active and produced socioeconomic benefits to residents over time. This is despite ideological shifts that are evident in public policy and national data analysis. 


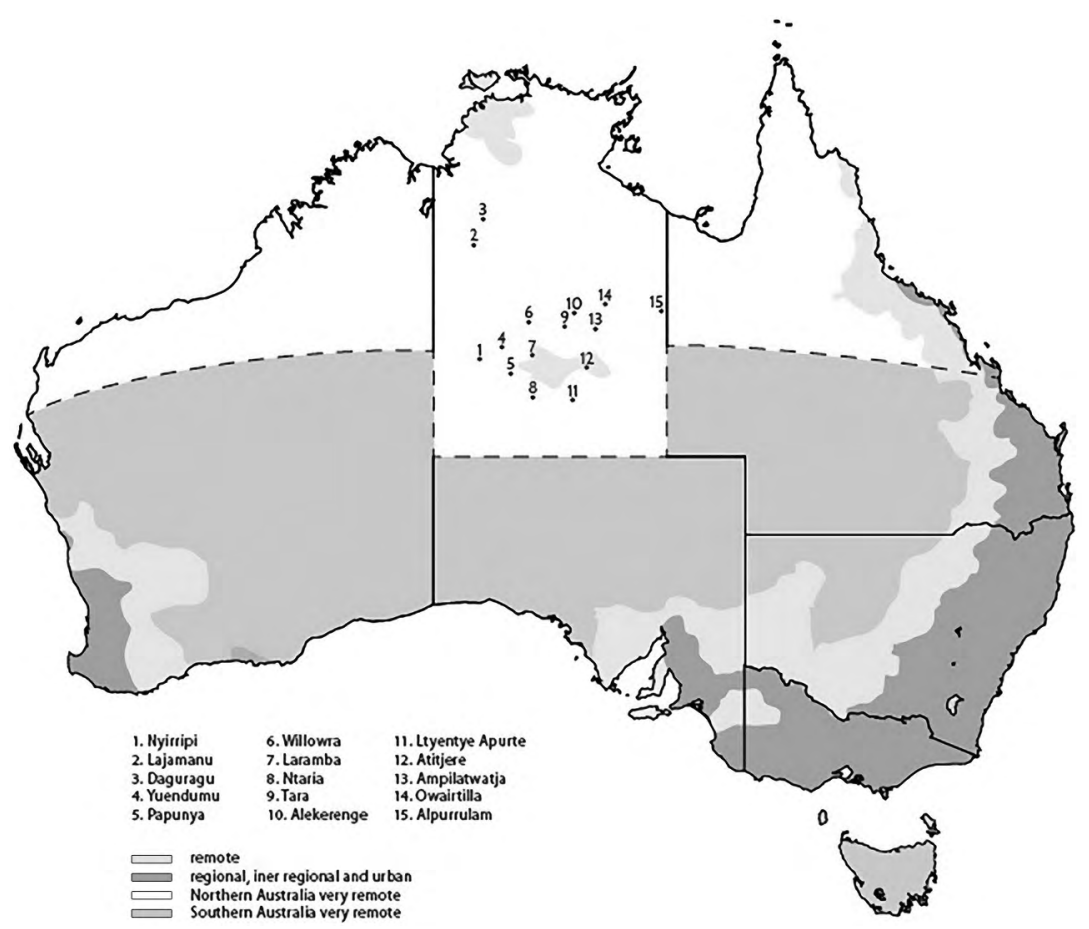

Figure 8.1: Map of Australia with remote, very remote and Northern Australia boundaries and including the 15 settlements studied for mixed-market activity.

Source: Ninti One Ltd (cartographer) and J. Lovell.

Non-markets are a category that includes governments, charities, not-forprofits and philanthropies. Non-markets exist when inputs are un-costed (Wolf, 1993). These institutions seek the equitable distribution of social and economic benefits in sectors where markets have failed or are not active (Wolf, 1993, p. 6). Markets are places where goods and services are openly traded and are priced. This chapter uses these terms in preference to the dualistic public versus private categorisation, which have severe conceptual limitations when describing the socioeconomics of these settlements (see Chapter 9). Mixed-markets are conceived as the mesh in which market and non-market traits interact along with customary forms of socioeconomic activity. In terms of the public data available to inform policy about remote economic participation, the sources of national data lack the definition required to accurately describe or interpret the impacts of mixed-markets at settlement level (Lovell et al., 2015b, p. 10). 
Mixed-market activity shares features of socioeconomic benefit with social enterprises in other countries (Lovell et al., 2016). In two advanced market democracies, Canada and Australia, the constraints of national quantitative data and the lack of typological qualitative definition (McMurtry \& Brouard, 2015; Sengupta et al., 2015) have prevented useful distinctions between social enterprises as market, mixed-market or non-market models. These constraints ignore evidence of historic context and other points of difference, such as culture and gender (Sengupta et al., 2015, p. 110), which distinguish settlement-level economic activity otherwise absent in the national data. The effect within the broad categories of market, non-market and Canadian Indigenous social enterprise (Sengupta et al., 2015) is that little information is available to contribute to understanding the agency required by local entrepreneurs (Pearson \& Daff, 2014) or the usefulness of models of enterprise available under current legislation (Sengupta et al., 2015). Due to the constraints in remote population data and methodology, residents of sparsely populated regions experience unintended consequences of policy interventions in ways seldom experienced by larger populations of urban residents.

Analysis of the national and industry data available (see Chapter 9) suggested non-market interventions may have worked against the intended outcomes of policy in some of the remote settlements in the study area in Australia. There is evidence that non-markets failed to produce the intended equitable distribution of financial or social capital among employed residents in the study region. There were lower rates of Indigenous employment and lower average incomes for Indigenous residents in 2011 than in 2006 (ABS, 2012). The following points consider the configurations of ideology and remoteness that underpin conceptualisation of remote socioeconomic activity. Different and sometimes competing configurations are present, which, if unacknowledged, reduce opportunities for everyday market and mixed-market activity.

\section{Tipping Points}

This chapter furthers the proposition that mixed-markets can provide a successful interface between non-markets, markets and residents as entrepreneurs acting collectively or individually. It seems there is a paradox between the priorities of the non-market and the aspirations of Aboriginal and Torres Strait Islanders that are neither classified through the 
geographic construct of 'remoteness' (ABS, 2013), nor represented by the national consensus of Australian values (Lovell et al., 2014). The agenda of developing Northern Australia is a tipping point at which entrepreneurial and mixed-market activity should be high on local, regional and national agendas (Morrison, 2015). Realistically, the management of unemployed adult residents into work programs remains the most dominant nonmarket response to remote economic participation at a settlement level in remote Australia (Moran \& Porter, 2014). Current Australian welfare to work programs align with the 'liberal welfare' policies of a number of other developed nations (Whiteford, 2015, para. 7).

Since 2008, the impact of the global financial crisis on local, regional and national markets contributed to changes in mixed-market activity in the clusters of settlements in this chapter. There was a downturn in the value of products from remote Australian Aboriginal art centres entering the market after 2007 and an increase in the number of products entering the market at lower price points (Acker \& Woodhead, 2015, p. 17). Also formalised in 2008, was the increasingly centralised approach of all tiers of government to the policy of Closing the gap on Indigenous disadvantage (Council of Australian Governments, 2008; Department of Families, Housing, Community Services and Indigenous Affairs, 2008). This program rerouted non-market expenditure into national priorities that continue to be a standard measure of non-market success or failure (Australian Government, 2015a). Additionally, in 2008, the Northern Territory Government undertook the 'largest scale, forced local government amalgamation in Australia' (Tiley \& Dollery, 2010, p. 3) by restructuring local Aboriginal government authorities into large regional shires that operate from centralised service centres in a hub-and-spoke model (Local Government Association of the Northern Territory, 2014).

The Australian Government's Department of Industry green and white papers for the development of Northern Australia (Australian Government, 2014a, 2015c) do not mention the aspirations and capacity of the residents of remote settlements. This results in policy confusion at the local level because sustainable and prosperous businesses are priorities in the national policies contained in the Indigenous Advancement Strategy (IAS) that was developed by the Department of Prime Minister and Cabinet (Australian Government, 2014b). Earlier analysis of mixed markets confirms that remote Aboriginal and Torres Strait Islanders do not appear as consumers, producers or suppliers of markets or industries in census data (Lovell et al., 2015a) or in the policy papers mentioned. 
There has been little attention paid in the public policy planning phases to bring distinctly different ideological positions and responses into public discussion of sustainable development (Morrison, 2015).

This omission leaves policy intentions and potential outcomes poorly understood from both the standpoint of Aboriginal and Torres Strait Islander custodians in Northern Australia and the dominant neoliberalism represented in national and territory governments' policy regarding sustainable Northern Australian development. The alternative to marketbased employment or entrepreneurial activity in remote settlements is active social policy, currently called the Community Development Programme (Australian Government, 2015b). This is a 'work for the dole' employment activity. Correspondingly, the evidence of mixed markets in the clusters of 15 settlements suggests art centres, ranger programs and community researchers' activities have continued despite the unintended consequences of national policy decisions (Carson \& Carson, 2014).

\section{Multidirectional Remoteness}

Government and other non-market service providers have made use of geographic, spatial and demographic measures to classify settlements as remote or very remote as a measure of distance from the nearest regional or urban service centre. This classification is known as the Australian Statistical Geography Standard (ASGS) (ABS, 2012) through which approximately 86 per cent of the landmass and 2.8 per cent of the Australian population are classified as remote and very remote regions and residents. The use of this system of classification for policy and program development has funding and cost implications that affect the potential development of markets, non-market service delivery, taxation, governance and the prevalence or lack of infrastructure. Remoteness is frequently listed as a major contributor to market failure (Productivity Commission, 2014, p. 97).

In the ASGS framework, remoteness is a measure of disadvantage that is calculated against the sustainability of settlements (Morris et al., 2010), resource extraction opportunities (Foran et al., 2015), procurement practices (Dockery, 2014a), the resilience and vulnerability of marginalised regions and residents (Maru et al., 2014) and, most recently, the Northern Australian development agendas (Australian Government, 2015c; Carson et al., 2014; Mayes et al., 2014; Northern Territory Cattlemen's Association, 2014). The ASGS informs national polity and 
ideological positions, which are in turn subject to the forces of global, neoliberal developed economies (McMurtry \& Brouard, 2015). Whether the tension is seen as top down or bottom up, in the neoliberal context the modification of non-market services, resources and opportunities is aimed at changing individual behaviours to align more closely with dominant ideological aspirations (Nethercote, 2015). The expectations, market-drivers and historical contexts generally reflect urban derivations and are inadequate as ways of configuring for remoteness.

The themes of remoteness and ideology cited in previous mixed-market analysis resonate with wider research synthesis and integration. In remote Australia, as elsewhere, research synthesis - as the bringing together of themes and findings across disciplines, stakeholders and programs-are part of 'a dynamic world, where everything is changing all the time' (Bammer, 2015, p. 289). This chapter is part of a synthesis and integration of the research programs of contiguous Cooperative Research Centres (CRCs) that are 'concerned with delivering solutions to the economic challenges of remote Australia' (Ninti One Ltd, 2010). The concept of 'remoteness' has emerged as contradictory when it is as much perceptual, social and temporal as it is proximal and spatial (Jacobsen \& Tiyce, 2014). The lived experience of many residents in regional, remote and very remote Australia is that urban centres and populations are distant from those out bush in more ways than geographic (Woinarski et al., 2014). Remoteness conceived as multidirectional reveals complexity is at the heart of The modern outback (Woinarski et al., 2014). Geographers (Walker et al., 2012) argue that to reignite insight of remote human and natural landscapes is essential to the public interest. The future of regions and access to remote resources on which the national economy relies (Australian Government, 2014b, 2015c) depends on an articulation of complex multidirectional remoteness.

While recognising that the major limitations of national data are ideological and methodological, it is also evident that the dominance of non-market activity requires rethinking in relation the sustainable development of Northern Australia. Entrepreneurship is defined by the OECD (2015, p. 11) as 'the enterprising human action in pursuit of the generation of value' and entrepreneurial activities are 'not always related to the creation of financial wealth; for example, they may be related to increasing employment, tackling inequalities or environmental issues'. While there is an international literature exploring the value of entrepreneurship in relation to socioeconomic and wellbeing benefits (International Comparative Social Enterprise Models, 2013), this is 
not reflected in current Australian Indigenous policy and seems to lack the rhetorical fit with more recent and dominant ideology regarding employment and economic benefit for remote residents (Forrest, 2014; Wunan Foundation, 2015).

It is unsurprising that the recent mixed-market analysis reflects the near saturation of publicly funded employment initiatives when:

the entrepreneurial culture in a country affects the attitude that individuals have towards entrepreneurship, the likelihood of choosing entrepreneurship as a career, the ambitions to succeed and start again after a failure or the support provided by family and relatives planning to set up a business. (OECD, 2015, p. 109)

Since colonisation, Australians have had a strong historical preference to first turn to government for funding and support of markets described as a form of 'colonial socialism' making entrepreneurship a secondary consideration in many cases (Barnard et al., 1982, pp. 320-321). Mixed markets are one glimmer of an entrepreneurial tendency that is sustained by the forms of capital central to the residents of remote Aboriginal settlements and which prevails despite the non-market reframing of remoteness and Indigeneity as forms of disadvantage (Guenther, 2015).

Adding yet another layer of complexity to policy development in remote and very remote Australia, human, cosmological and ecological structures in the modern outback (see Figure 8.2) reflect an extensive temporal continuity that existed pre-colonisation (Lovell, 2015; Maru et al., 2014). This continues to contribute to a presence in which 'Aboriginal people, lands, culture and socio-economic concerns are writ far larger than in a national context' (Woinarski et al., 2014, p. 33). Where land and waterways were once managed through kinship estates among language groups, various leaseholds also now cover and overlap the continent. Lease distributions in the arid and very arid regions of Australia that Woinarski et al. (2014, p. 121) defined as the modern outback are approximated as:

- 50 per cent pastoral leases

- 20 per cent conservation reserves

- 20 per cent Aboriginal-owned land

- 19 per cent unallocated crown lands

- >4 per cent intensive horticulture or forestry

- $>1$ per cent military use. 


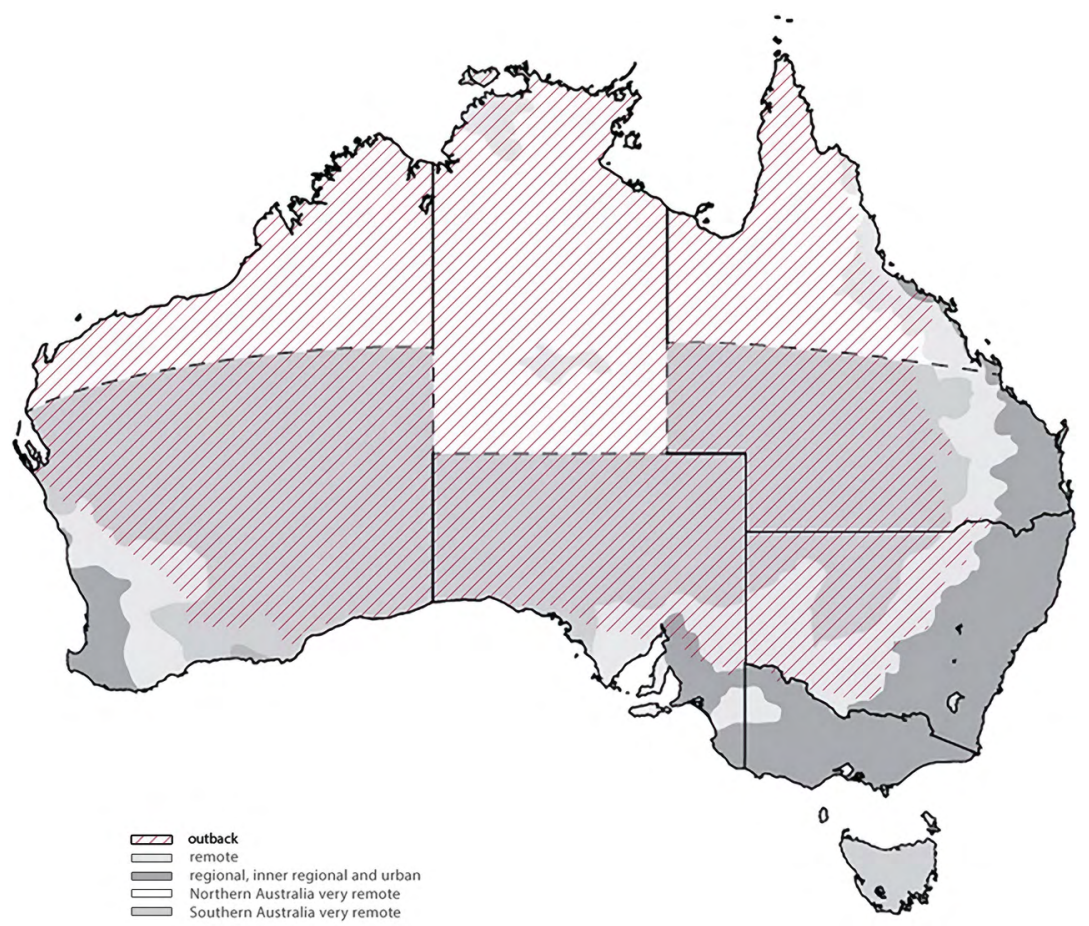

Figure 8.2: 'Outback' region of the Australian continent, including remote, very remote and Northern Australia regions.

Source: Woinarski et al. (2014).

Contemporary systems of leasehold and overlapping jurisdictions are cited by governments and industry as one of the most serious constraints for sustainable development throughout remote Australian regions (Forrest, 2014). The land tenure associated with such leases does not always reflect land use while mining and exploration leases overlay other tenure types (Australian Government, 2015c; Chaney \& Walker, 2013; Morrison, 2015; Woinarski et al., 2014). Data regarding the flowon socioeconomic benefits to remote residents through leaseholds on Aboriginal Land is not publicly available. 


\section{The Invisibility of Non-Market Saturation}

Three tiers of government administer remote and very remote Australia and, despite the prevalence of Aboriginal residents, businesses and custodian in these regions, there is no tier equivalent to an Aboriginal level of government (Sengupta et al., 2015). Instead, not-for-profit land councils have been established as statutory authorities of the national government, meeting the multiple roles of representation of custodians, managers of public funds received as lease monies and negotiators of reparatory payments to traditional owners and land rights (Central Land Council, 2015a). Land rights are the prevalent legislated mechanism for recognition of the communal structures of Aboriginal 'ownership' of country and they recognise the connection of people to land as sovereign rights that pre-exist European law. Walker et al. (2012) have suggested that the long-term change needed in remote Australia would involve new governance principals, ones that 'create locally appropriate institutions which have sufficient authority, legitimacy and effectiveness to fulfil their functions' (p. 64). However, Walker et al.'s vision of that authority is one of 'dual compact' reliant on 'the general public and the parochial interest' being adequately reflected in a 'common set of goals'. This orchestrates new forms of non-market institutions that carry out the task of 'mandating, mediating and settling contests' (p. 64). There is little in that proposition that recognises pre-existing sovereignty and standpoints within which social and economic systems of collaborative ownership, reciprocal responsibility and kinship ties already determine the socioeconomic multipliers and exchanges that benefit remote residents. Yet again, the solutions to the perceived problems of the outback are framed in ways that demand more non-market intervention and the eternal quest for better coordination between institutions.

While Woinarski et al. (2014) argued for modernisation of the outback and Walker et al. (2012) for its preservation, both recognised that systems of Aboriginal sovereignty have been in use to manage and define the human ecology of the continent over thousands of years. Both argued for increased non-market mediation for modernisation and preservation, yet non-market policy continues to consistently backfire against priority equity targets for employment and economic participation. Mixed markets represent an alternative entrepreneurial behaviour that can be responsive over time to changes in non-market polity (Acker \& Woodhead, 2015; Central Land Council, 2015b; Woodhead \& Acker, 2015). 
Rather than redesigning the activity of an already immense group of nonmarket stakeholders in remote Australia as Walker et al. (2012) suggested, Lovell et al. (2015b) identified instances of successful mixed-markets. These are interfaces that challenge the misplaced assumption that national measures of disadvantage account for the advantages of local culture and capacity (Central Land Council, 2015b; Desart, 2014; Ninti One Ltd, 2014).

\section{Ideology and Intervention}

It is the role of public policy to change the behaviour of the individual (Australian Public Service Commission, 2007), but the directives for change are based on population-level findings, combined with political aspirations and a governable populous. Currently, political aspirations occur in the context of critical discourse and neoliberal pragmatics (Hamilton, 2014; Nethercote, 2015; Whiteford, 2015) that are refined further by the situation in which Australia is one of the most urbanised and wealthiest developed nations (Hugo et al., 2013; Levine et al., 2015). The analysis of mixed-market activity described in earlier work (Lovell et al., 2015a) has revealed a resilience-among markets and producers - that continues despite changes in the direction that welfare and employment policies have taken in remote settlements.

In combining 150 program areas down to five priorities, the national IAS argued a framework within which children attend school and adults go to work in safe communities will ensure the wellbeing and health of residents (Australian Government, 2014b). This does not readily account for the ways that markets may intersect with and value remote Aboriginal custom, capacity or advantage (Larkin, 2009; Lovell, 2015; Zander et al., 2014), nor value Aboriginal and Torres Strait Islander longitudinal temporal and sovereign corporate knowledge (Ardill, 2013; Babie, 2013; Morrison, 2015). The IAS is aligned with Australia's liberal welfare policy, which is one of the major mechanisms through which the nation redistributes wealth in ways that provide for the marginalised and disadvantaged (Whiteford, 2015). Hamilton (2014, p. 453) argued that moving welfare policy via programming and implementation towards 'the individualisation of risk' aligned with neoliberalism has shifted emphasis from shared responsibility 
(individuals and the state) to responsible citizenry, in which the individual is expected to behave as an 'entrepreneurial self' bound to welfare through contractual arrangements.

Previous analysis identified that residents derive socioeconomic benefits from mixed markets (Lovell et al., 2015a; Lovell et al., 2016) through their capacity to use local assets — such as natural, cultural, social and knowledge capitals — to produce products or services with a market value. These assets are 'valued' quite differently by custodians, non-markets and markets (Lovell et al., 2015a, p. 3) and it is in an interface of activity, opportunity and transaction that residents derive socioeconomic benefits. Much of this asset base is collectively owned and managed and must be negotiated in addition to structures of the market place (Pearson \& Daff, 2014). Sengupta et al. (2015) described a model of Indigenous social enterprise in which a quadruple bottom (social, cultural, environmental and financial benefits) line drives the aspirations and goals of any such organisation, but this remains contested among Indigenous scholars (Wuttunee, 2010).

In Australian policy, there is a difference in the remote welfare to work contract from programs applied to urbanites on the grounds of remoteness (see Australian Government, 2015a). This is a nuance that assumes Aboriginal residents in remote settlements are homogeneously disadvantaged and marginalised differently than city folk and need to work additional hours to receive their welfare payment (Altman, 2015). The close association of people of the land to trade, exchange, reciprocity and demand sharing is part of the inter-generational inheritance from those who managed the human ecology of homelands across the nation for thousands of years prior to European settlement and ensuing urbanisation (Woinarski et al., 2014). Indigenous sovereignty remains a fact of life. While not arguing for a return to pre-award wage economics, this chapter does question the standpoint in which the non-market intervention is one in which remoteness and Indigeneity are classified as disadvantages (Guenther, 2015). Currently, public services designed to counter remote disadvantage procure financial multipliers, often through private nonmarket actors, who are increasingly non-local and non-Indigenous and whose social and economic benefits are mostly redirected away from remote settlements, and in many cases, remote regions (see Chapter 9 for analysis of income data by Indigenous or non-Indigenous status). 


\section{Convergence in Mixed-Markets in Remote Contexts}

Analysis of the socioeconomic benefits derived from mixed markets is a theme from industry sector research in the CRC for Remote Economic Participation (CRC-REP) and wider academic and industry information. The flow of local enterprise back into settlements or membership cohorts and the concept of an interface of customary, market and state interests is not entirely new and has some features common with social enterprise (International Comparative Social Enterprise Models, 2013). Assessing from the settlement level, mixed markets appear to mesh market-type behaviours of customers who are prepared to pay for products and services with the local producers who have the assets required to provide them (Lovell, 2015).

Non-Indigenous and Indigenous researchers (Altman, 2015; Pearson, 2014; Sanders, 2015) analyse the socioeconomics of remote Indigenous settlements to inform public policy and public interventions. Altman (2007, p. 3) described 'customary economies' as interacting contributing factors along with market and state (government) in remote economies. He framed these as 'hybrid economies' and the concept has remained in use by some and contested by others for more than a decade (Langton \& Mazel, 2008; Russell, 2011). Mixed markets are conceptualised from the standpoint of non-Indigenous researchers who have used national data sets to seek evidence of the remote industry activities of which they also have practical experience. Customary economies are embedded deep in the Aboriginal mediation of changing socioeconomic, cultural and natural human ecology (Lovell, 2015; Wallace \& Lovell, 2009) and include forms of human capital aligned with Aboriginal standpoints and sovereignty (Ardill, 2013). The focus of mixed-market analysis to date has been how the interface where residents access market opportunity is counted (or not) through the systems of national data collection that inform policy. Entrepreneurial residents in remote settlements are increasingly influenced by the social welfare contracts and employment opportunities that are regulated by non-markets, yet residents continue to derive mixed-market socioeconomic benefits through products and services that rely on their local assets and sovereignty to supply markets. 
The wider literature confirms that at settlement level a fit between local residents' aspirations, non-market and market is essential if socioeconomic activities are to succeed (Taylor et al., 2015). Mixed markets have produced socioeconomic benefits and remained active over time despite:

- proscribed non-market priorities including changes in behaviour to reflect the requirements of active social policy

- the impact of global markets on remote local markets

- the obscurity of mixed-market activities to policymakers and consumers of services and products (Lovell et al., 2015a, p. 16).

In contrast, the marketisation of government human service provision has created a type of 'market' behaviour among non-market providers-both commercial and not-for-profit-who are predominantly non-local and whose profits are removed from the local community without providing local multiplier benefits. The cash flow from this non-market market derives from the delivery of public services such as health, education and employment programs into remote settlements (Markham \& Doran, 2015). In the original study region, public service delivery accounted for an increase in the number of non-local staff employed at higher income levels (ABS, 2014a) between collection points in 2006 and 2011. Significant policy-driven intervention into public service provision and an increasingly contractual basis for obligational welfare (Nethercote, 2015) has driven the use of non-local and non-remote agencies to provide remote public services (Australian Government, 2014b). There is evidence that provision of remote housing, transport and communications for staff working in remote settlements has not improved local market or mixed-market activity or stimulated financial input into local economies through multiplier industries (see Chapter 9). Correspondingly, there is little infrastructure that supports visitor flow between settlements. Public transport is limited and delivered at high cost per capita (Spandonide, 2014), visitor facilities and local protocols for visitors are lacking and mobile communication is limited (Rennie et al., 2013).

In keeping with Wolf's (1993) theory, market and non-market are understood to derive success or failure through the distribution of a service or product, where success represents equitable and efficient costs and benefits. This theory opens to the convergence of complexity and critical success factors, among which correction of distributional inequities occurs through the one or more form: 
- regulated industry

- production of public goods

- redress of market imperfection or failure.

Any of these redistributions 'place authority in the hands of some to be exercised over others' (Wolf, 1993, p. 83). The 'entrepreneurial self' is bound to a contract-type arrangement of active social policy-through taxation, welfare and superannuation (Whiteford, 2015) within an advanced market democracy. In the remote Aboriginal settlement context, the entrepreneurial self is additionally accountable to collectivised socioeconomic structures of sovereignty. The Indigenous entrepreneur manages the expectations of market-based supply and demand and obligations derived through kinship structures (Pearson \& Daff, 2014).

Whiteford (2015, para. 10) suggested that 'another way of classifying and evaluating alternative welfare state arrangements is on the basis of the forms of redistribution they emphasise'. Policies that promote more market-driven behaviours to remote residents are based on significant 'private' employment. This so-called 'private' category of employment actually masks many people who are working for non-market entities, such as employment agencies, philanthropies and charities. Thus, this misrepresentation reported in the census data is likely to contribute to unintended programmatic outcomes. Forrest's (2014) policy for labour market activity is based on assimilation from customary and custodial economies to those of open and competitive markets. This policy drives behaviour-changing contracts through active social welfare on the assumption that economically rational behaviour will increase human capital capacity and cause behaviours conducive to neoliberal homo economicus aspirations. However, the socioeconomics of remote settlements suggest determinants of capital that stem from customary and cultural standpoints dominate and are not altogether those of neoliberal idealism (Altman \& Kerins, 2012).

\section{A Changed Pre-Notion}

Developing tourism as sustainable enterprise is a pillar in the policy for Northern Australian development (Australian Government, 2015c, p. 2). Currently, tourism reflected in the policy focuses on generating business between non-local tourists, iconic visitor locations and specialist tourism 
products and experiences. Tourism is a means of economic redistribution in rural, remote and regional settlements. It is a form of allocation through which local products or services have a transactional value in the market (Zeng, et al., 2015). The Northern Territory Government initiative to link Aboriginal tourism products to the opportunities of northern development reflects priorities aligned to Indigenous tourism with socioeconomic benefits to include remote Indigenous employment outcomes (Northern Territory Government, 2015).

As a theoretic case study, Indigenous tourism is used here to consider the impact of mobility of visitors on the redistribution of socioeconomic benefits at a settlement level, which requires a shift in thinking. Taylor et al. $(2015$, p. 10$)$ posed the question why not prioritise amenities for local Aboriginal residents who move between settlements, and reconceptualise their contribution through mobility, as local tourists. Mobility that results in local tourism produces a financial flow through increased local spending (fuel, shopping, power, etc.), while the same movement away from settlement of origin has the reverse effect (Dockery, 2014b; Spandonide, 2014). The opportunistic and ad hoc behaviours that contribute to local mobility are not envisaged as market opportunities through policy and program design (Carson et al., 2014) but are managed as problematic in most service delivery scenarios.

Reconceptualising locally mobile residents as 'tourists' engaged in market behaviours as proposed by Taylor et al. (2015) is not without difficulty. Most often, those who are mobile between settlements are described as 'visitors', both in census data collection (ABS, 2014b) and in conversation among residents (Amunda Gorey, personal communication, 2011). In research consultations for ABS (2014b) about Indigenous perspectives on homelessness, the complexity of the expectations between Indigenous visitors and hosts is clear but not uniform across families, settlements, age groups and genders. The consulting group felt there was an opportunity to take the discussion further in relation to public housing as an instrument for organising and managing the flow of visitors at a settlement level, but this was not part of the research work. However, the opportunity for settlement-based responses to visitor/tourist facilities, via the instruments of existing public housing, is not without attributes common to the other mixed-markets of art centres, ranger programs and community researchers. 
Non-markets respond to mobility of the same demographic groupremote Indigenous residents-differently across services. The impacts of mobility on educational service design and programming (Prout $\&$ Yap, 2012) are perceived as problematic and detrimental to the students' progress in learning, yet through the lens of certain social and cultural determinants, mobility is the correct response and contributes to the social and cultural capital of the individual (See Alice, school attendance, in Lovell et al., 2014). Access to country and cultural activity is shown to be beneficial in self-assessed wellbeing indices, including where this involves mobility, and reported benefits include social and cultural capital, and transfer of these into activities with socioeconomic benefits (Biddle, 2012).

\section{Conclusion and Further Comments}

Using Wolf's (1993) criteria of market and non-market, it is clear that employment data from previous studies have produced findings that suggest an almost exclusively non-market economy exists in at least some regions of remote Australia. This is further determined through the data in which almost all employees report working for businesses they do not own. There appears to be close to zero 'market' activity, prompting the observation that the outsourcing of public services from government to other providers has not created market activity and the census data does not disclose the nature of 'private sector' as essentially non-market. Yet the ideological configurations in which these findings occur highlight a significant non-alignment exists in the perception of what works and what is work between urban and remote constituents. Applying a multidirectional understanding of remote Australia as a saturated non-market allows a transition to a more fit-for-purpose mixed-market. This brings with it the opportunity for local financial multipliers, economic and sociocultural benefits that can be generated and retained in remote settlements.

\section{References}

Acker, T. \& Woodhead, A. (2015). The economy of place, a place in the economy: A value chain study of the Aboriginal and Torres Strait Islander art sector. Summary report. Retrieved from nintione.com.au/resource/EconomyOfPlace/files/assets/ basic-html/page-1.html 
Altman, J. (2007). Alleviating poverty in remote Indigenous Australia: The role of the hybrid economy. Retrieved from pdfs.semanticscholar.org/373f/94ba0f8 ccd6a8d0b4c5218c98fd3bce97d5b.pdf

Altman, J. (2015, February-March). Indigenous policy 'reform'. ARENA Magazine, pp. 10-12.

Altman, J. \& Kerins, S. (Eds). (2012). People on country, vital landscapes, Indigenous futures. Annandale, NSW: Federation Press.

Ardill, A. (2013). Australian sovereignty, Indigenous standpoint theory and feminist standpoint theory: First Peoples' sovereignties matter. Griffith Law Review, 22(2), 315-343.

Australian Bureau of Statistics (ABS). (2012). Australian statistical geography standard (ASGS): Volume 5-remoteness structure, July 2011 (Cat. No. 1270.0.55.005). Retrieved from www.abs.gov.au/AUSSTATS/abs@.nsf/DetailsPage/1270.0.55. 005July\%202011

Australian Bureau of Statistics (ABS). (2013, 29 October). Glossary of statistical geography terminology, 2013 (Cat. No. 1217.0.55.001). Retrieved from www. abs.gov.au/ausstats/abs@.nsf/mf/1217.0.55.001

Australian Bureau of Statistics (ABS). (2014a, 18 December). Australian demographic statistics (Cat. No. 3101.0). Retrieved from www.abs.gov.au/AUSSTATS/abs@. nsf/Lookup/3101.0Main+Features1Dec+2014

Australian Bureau of Statistics (ABS). (2014b). Information paper: Aboriginal and Torres Strait Islander peoples perspectives on homelessness (Cat. No. 4736.0). Retrieved from abs.gov.au/ausstats/abs@.nsf/mf/4736.0

Australian Government. (2014a). Green paper on developing Northern Australia. Canberra, ACT: Department of the Prime Minister and Cabinet. Retrieved from www.industry.gov.au/sites/default/files/2019-09/green-paperon-developing-northern-australia.pdf.

Australian Government. (2014b, 9 April). Indigenous Advancement Strategy. Indigenous Affairs. Retrieved from www.indigenous.gov.au/indigenousadvancement-strategy

Australian Government. (2015a). Closing the gap. Prime Minister's report 2015. Canberra, ACT: Australian Government. Retrieved from pmc.gov.au/sites/ default/files/publications/Closing_the_Gap_2015_Report.pdf

Australian Government. (2015b). The community development programme. Retrieved from www.dese.gov.au/community-development-program-cdp 
Australian Government. (2015c). Our north, our future: White paper on developing Northern Australia. Retrieved from www.industry.gov.au/data-and-publications/ our-north-our-future-white-paper-on-developing-northern-australia

Australian Public Service Commission. (2007). Changing behaviour: A public policy perspective. Canberra, ACT: Australian Government. Retrieved from legacy.apsc.gov.au/changing-behaviour-public-policy-perspective

Babie, P. (2013). Sovereignty as governance: An organising theme for 'Australian' property law. University of New South Wales Law Journal, 36(3), 1075-1108.

Bammer, G. (2015). An approach to understanding change. In G. Bammer (Ed.), Change! Combining analytic approaches with street wisdom. Canberra, ACT: ANU Press. doi.org/10.22459/CCAASW.07.2015.01

Barnard, A., Butlin, N. \& Pincus, J. (1982). Government and capitalism: Public and private choice in twentieth century Australia. Sydney, NSW; Boston, MA: Allen \& Unwin.

Biddle, N. (2012). Measures of Indigenous social capital and their relationship with well-being. Australian Journal of Rural Health, 20(6), 298-304.

Carson, D. \& Carson, D. (2014). Local economies of mobility in sparsely populated areas: Cases from Australia's spine. Journal of Rural Studies, 36, 340-349.

Carson, D., Carson, D. \& Lundmark, L. (2014). Tourism and mobilities in sparsely populated areas: Towards a framework and research agenda. Scandinavian Journal of Hospitality and Tourism, 14(4), 353-366.

Central Land Council. (2015a). CLC homepage facts. Retrieved from www.clc. org.au/

Central Land Council. (2015b). Ranger program development strategy. Retrieved from www.clc.org.au/publications/content/ranger-programdevelopment-report

Chaney, F. \& Walker, B. (2013). Governance at the heart of reform in remote Australia. Paper presented at the 12th National Rural Health Conference: Strong Commitment Bright Future, Adelaide, South Australia. Retrieved from www.ruralhealth.org.au/12nrhc/wp-content/uploads/2013/06/Chaney-Fred_ Walker-Bruce_ppr.pdf

Council of Australian Governments. (2008). Closing the gap on Indigenous disadvantage. The Challenge for Australia. Retrieved from www.dss.gov.au/sites/ default/files/documents/05_2012/closing_the_gap.pdf 
Department of Families, Housing, Community Services and Indigenous Affairs. (2008). Increasing Indigenous employment opportunity: Proposed reforms to the CDEP and Indigenous employment programs.

Desart. (2014). Desart. Culture first. Retrieved from desart.com.au

Dockery, A. (2014a). The mining boom and Indigenous labour market outcomes. In M. Brueckner, A. Durey, R. Mayes \& C. Pforr (Eds), Resource curse or cure? On the sustainability of Western Australia (pp. 75-89). London, England: Springer.

Dockery, A. (2014b). Reconceptualising mobility for Aboriginal and Torres Strait Islander Australians. Retrieved from www.crc-rep.com.au/resource/CW015_ ReconceptualisingMobility.pdf

Foran, T., Williams, R., Spandonide, B., Fleming, D., Race, D. \& Dowd, A. (2015). A conversation about energy futures for remote Australian communitiestheory and detailed workshop findings. Retrieved from www.crc-rep.com. au/resource/CW022_ConversationEnergyFuturesRemoteCommunities_ Theory.pdf

Forrest, A. (2014). Creating parity - The Forrest review. Canberra: Commonwealth of Australia. Retrieved from www.niaa.gov.au/resource-centre/indigenousaffairs/forrest-review

Guenther, J. (2015). The advantaged and disadvantaged of remote schools. Retrieved from www.crc-rep.com.au/resource/Guenther_AdvantagedAnd DisadvantagedOfRemoteSchools.pdf

Hamilton, M. (2014). The 'new social contract' and the individualisation of risk in policy. Journal of Risk Research, 17(4), 453-467.

Hugo, G., Feist, H. \& Tan, G. (2013). Australian Population \& Migration Research Centre policy brief. Retrieved from arts.adelaide.edu.au/hugo-centre/\#

International Comparative Social Enterprise Models. (2013, 28 September). Introduction. International Comparative Social Enterprise Models. Retrieved from www.iap-socent.be/icsem-project

Jacobsen, D. \& Tiyce, M. (2014). Aboriginal and Torres Strait Islander tourism enterprise approaches to creating value for visitors in remote Australia (Report CR003). Retrieved from www.crc-rep.com.au/resource/CR003_Aboriginal TorresStraitIslanderTourismEnterprisesCreatingValue.pdf

Langton, M. \& Mazel, O. (2008). Poverty in the midst of plenty: Aboriginal people, the resource curse and Australia's mining boom. Journal of Energy and Natural Resources Law, 26(1), 31-65. 
Larkin, S. (2009). Race blindness in neo-liberal and managerial approaches to Indigenous administration. International Journal of Critical Indigenous Studies, 2(1), 36-42.

Levine, J., Chan, K. M. \& Satterfield, T. (2015). From rational actor to efficient complexity manager: Exorcising the ghost of Homo economicus with a unified synthesis of cognition research. Ecological Economics, 114, 22-32.

Local Government Association of the Northern Territory. (2014). Local Government Association of the Northern Territory fact sheets. Retrieved from www.lgant.asn.au/wp-content/uploads/2017/06/2017-06-01-Fact-Sheet-1LGANT.pdf

Lovell, J. (2015). Customary assets and contemporary artistry: Multimodal learning and remote economic participation. The Australian Journal of Indigenous Education, 42(2), 184-193. doi.org/10.1017/jie.2015.24.

Lovell, J., Blake, S., Alice, T. \& Wallace, K. (2014). Red dirt service economies: A picture of trade-offs and choices. Journal of Australian Indigenous Issues, 17(4), 131-151.

Lovell, J., Guenther, J. \& Zoellner, D. (2015a, 20-22 July). Developing Northern Australia: Recognising remote mixed-market economies. Paper presented at the Developing Northern Australia: Economically, Socially, Sustainably conference, Townsville, Queensland.

Lovell, J., Guenther, J. \& Zoellner, D. (2015b). Northern Australian aspirations. Retrieved from www.cdu.edu.au/sites/default/files/researchbrief-2015-07_0.pdf

Lovell, J., Zoellner, D., Guenther, J., Brouard, F. \& McMurtry, J. (2016). Contemporary Aboriginal settlements: Understanding mixed-market approaches. In A. Taylor, D. B. Carson, P. C. Ensign, L. Huskey, G. Saxinger \& R. Rasmussen (Eds), Settlements at the edge: Remote human settlements in developed nations (pp. 246-269). Gloucester, England: Edward Elgar.

Markham, F. \& Doran, B. (2015). Equity, discrimination and remote policy: Investigating the centralization of remote service delivery in the Northern Territory. Applied Geography, 58, 105-115.

Maru, Y., Smith, M., Sparrow, A., Pinho, P. \& Dube, O. (2014). A linked vulnerability and resilience framework for adaptation pathways in remote disadvantaged communities. Global Environmental Change-Human and Policy Dimensions, 28, 337-350. 
Mayes, R., McDonald, P. \& Pini, B. (2014). 'Our' community: Corporate social responsibility, neoliberalisation, and mining industry community engagement in rural Australia. Environment and Planning A, 46(2), 398-413.

McMurtry, J. \& Brouard, F. (2015). Social enterprises in Canada: An introduction. ANSERJ: Canadian Journal of Nonprofit and Social Economy Research/Revue canadienne de recherche sur les OSBL et l'économie sociale, 6(1), 6-17.

Moran, M. \& Porter, D. (2014). Reinventing the governance of public finances in remote Indigenous Australia. Australian Journal of Public Administration, 73(1), 115-127.

Morris, R., Callaghan, R. \& Walker, B. (2010). Rural-remote and Indigenous Local Government: Western Australian scoping study. Retrieved from www. researchgate.net/publication/258839482_Rural-remote_and_Indigenous_ Local_Government_Western_Australian_Scoping_Study_Report

Morrison, J. (2015). Northern development: Embracing the Indigenous difference [Press release]. Retrieved from www.nlc.org.au/uploads/images/Joe-Morrison2015-NLC_JM_NPC_Address.pdf

Nakata, M. (2007). The cultural interface. The Australian Journal of Indigenous Education, 36(5), 2-14.

Nethercote, M. (2015). Neoliberal welfare, minorities and tenancy support. Social Policy and Society, 16(1), 15-32.

Ninti One Ltd. (2010, 1 April). About CRC-REP. Cooperative Research Centre for Remote Economic Participation. Retrieved from crc-rep.com/

Ninti One Ltd. (2014). The key to the community intelligence of remote Australia. Retrieved from www.nintione.com.au/resource/NintiOne_ACRProspectus_ TheKeyToTheCommunityIntelligenceOfRemoteAustralia.pdf

Northern Territory Cattlemen's Association. (2014). Northern Territory Cattlemen's Association. Retrieved from www.ntca.org.au/

Northern Territory Government. (2015). Indigenous Tourism Advisory Council to identify new job and business opportunities [Press release]. Retrieved from newsroom.nt.gov.au/mediaRelease/13471

Organisation for Economic Co-operation and Development (OECD). (2015). Entrepreneurship at a glance 2015. Paris, France: OECD Publishing. doi.org/ 10.1787/entrepreneur_aag-2015-en 
Pearson, C. \& Daff, S. (2014). Female Indigenous entrepreneurship in remote communities in Northern Australia. Information Management and Business Review, 6(6), 329-344.

Pearson, N. (2014). Quarterly essay 55. A rightful place: Race, recognition and a more complete commonwealth. Black Inc.

Productivity Commission. (2014). Graphic labour mobility. Retrieved from www. pc.gov.au/inquiries/completed/labour-mobility/report

Prout, S. \& Yap, M. (2012). 'No-one's really aware of where they are': A case study of Indigenous student mobilities in Australia's northwest. International Journal of Educational Research, 54, 9-20.

Rennie, E., Crouch, A., Wright, A. \& Thomas, J. (2013). At home on the outstation: Barriers to home Internet in remote Indigenous communities. Telecommunications Policy, 37(6-7), 583-593.

Russell, S. (2011). The hybrid economy topic guide. Canberra, ACT: ANU. Retrieved from caepr.cass.anu.edu.au/highlights/hybrid-economy-topic-guide

Sanders, W. (2015). Experimental governance in Australian Indigenous affairs: From Coombs to Pearson via Rowse and the competing principles (Centre for Aboriginal Economic Policy Research Discussion Paper No. 291). Canberra, ACT: ANU.

Sengupta, U., Vieta, M. \& McMurtry, J. (2015). Indigenous communities and social enterprises in Canada. ANSERJ: Canadian Journal of Nonprofit and Social Economy Research/Revue canadienne de recherche sur les OSBL et l'économie sociale, 6(1), 103-123.

Spandonide, B. (2014). Transport systems in remote Australia: Transport costs in remote communities (Working Paper CW017). Cooperative Research Centre for Remote Economic Participation. Retrieved from www.crc-rep.com.au/ resource/CW017_TransportCostsInRemoteCommunities.pdf

Taylor, A., Carson, D., Carson, D. \& Brokensha, H. (2015). 'Walkabout' tourism: The Indigenous tourism market for outback Australia. Journal of Hospitality and Tourism Management, 24, 9-17.

Tiley, I. \& Dollery, B. (2010). Historical evolution of local government amalgamation in Queensland, the Northern Territory and Western Australia. Retrieved from www.une.edu.au/_data/assets/pdf_file/0018/25416/02-2010x.pdf

Walker, B., Porter, D. \& Marsh, I. (2012). Fixing the hole in Australia's heartland: How government needs to work in remote Australia. Retrieved from eprints. utas.edu.au/15065/ 
Wallace, K. \& Lovell, J. (2009). Listen deeply: Let these stories in. Alice Springs, NT: IAD Press.

Whiteford, P. (2015, September). Tales of Robin Hood (part 1): Welfare myths and realities in the United Kingdom and Australia. Australian Review of Public Affairs Digest. Retrieved from www.australianreview.net/digest/2015/09/ whiteford.html

Woinarski, J., Traill, B. \& Booth, C. (2014). The modern outback. Nature, people and the future of remote Australia. Retrieved from www.pewtrusts.org/en/ research-and-analysis/reports/2014/10/the-modern-outback

Wolf, C. (1993). Markets or governments: Choosing between imperfect alternatives (2nd ed.). Cambridge, MA; London, England: MIT Press.

Woodhead, A. \& Acker, T. (2015). Productivity, income and gender: Aboriginal and Torres Strait Islander artists (Report CRO12). Retrieved from www.crcrep.com.au/resource/CR012_ProductivityIncomeGenderAboriginalTorres StraitIslanderArtists.pdf

Wunan Foundation. (2015). Empowered Communities: Empowered Peoples - Design Report. Retrieved from apo.org.au/node/245871

Wuttunee, W. (2010). Aboriginal perspectives on the social economy, co-operatives, and community economic development. Toronto, ON: Edmond Montgomery Press.

Zander, K., Dunnett, D., Brown, C., Campion, O., Daniels, C., Daniels, G., ... Carson, D. (2014). Indigenous cultural and natural resources management and mobility in Arnhem Land, Northern Australia. Human Ecology, 42(3), 443-453.

Zeng, B., Ryan, C., Cui, X. \& Chen, H. (2015). Tourism-generated income distribution in a poor rural community: A case study from Shaanxi, China. Journal of China Tourism Research, 11(1), 85-104. 
This text is taken from Leading from the North: Rethinking Northern Australia Development, edited by Ruth Wallace, Sharon Harwood, Rolf Gerritsen, Bruce Prideaux, Tom Brewer, Linda Rosenman and Allan Dale, published 2021 by ANU Press, The Australian National University, Canberra, Australia.

doi.org/10.22459/LN.2021.08 